\title{
11. 頝管内癌病変検索へのヒステロスコピーの有用性
}

\author{
（神戸市立中央市民病院産婦人科）
}

高島 英世

コルポスコピーで観察困難な 頝管内癌病変の診 断にヒステロスコピーを応用し, 病変の占拠部位, 広がり，進行程度を把握することを試みた。対象 は最近やく 5 年間に, 当院で手術を行い, 子宮頝 部縦軸方向の 8 分割切片で, 組織学的に確認した 上皮内癌 72 例, 微小侵潤癌 16 例, 扁平上皮侵潤 癌 44 例, 腺癌 9 例であり, 術前のヒステロスュ ピー所見を各癌病変につき, retrospective に検討し た. 観察方法は, 子宮胵部および 頝管内を $3 \%$ 酢 酸で加工した後, 腟内に生理食塩液をみたし, 腟 部表面を観察する。ついでヒステロスコープの先 端を外子宮口部に当てがうと, 噴出する生理食塩 液の水圧によって, 通常外子宮口が開大するので, ヒステロスコープを少しづつ頝管内に㨂入しなが ら観察する。その結果子宮腟部拉よび頝管内癌病 変の解剖学的占拠部位を 3 型に分類した. I 型は Ectocervix に限局するもの，II型は Ectocervix と Endocervix を占拠するもの，3 型は Endocervix に 限局するものである。I 型すなわち頝管内に 異常 所見を認めないものは, 上皮内癌が $66.7 \%$ で最も 多く, 微小浸潤癌 $43.8 \%$, 浸潤癌 $27.3 \%$, 腺癌 $11.1 \%$ の順に減少する. III型いわゆる純頝管型は, 上皮内癌 $6.9 \%$, 微小侵潤癌 $6.2 \%$ と共に少ない
が，扁平上皮侵潤癌では $29.6 \%$, 腺癌では $22.2 \%$ と増加した. 頝管内癌病変のヒステロスコピー所 見は, 近畿大学手島らの 3 段階のコルポ診所見細 分類に括扣むね準じて表現した. 頝管内病変は上 皮内癌で 24 例, 微小侵潤癌で 9 例, 扁平上皮侵 潤癌で 32 例にみられたが，概観すると各病変と もモザイクや赤点斑は少なく，あっても外子宮口 付近にほぼ限局し，白色上皮が多くみられ，頝管 上方に及ぶものもあった。 異常腺口は上皮内癌で $41.7 \%$ と最も多くみられ，微小侵潤癌 $92.2 \%$, 扁 平上皮侵潤癌は 0 であった。異型血管は上皮内癌 では, $\mathrm{aV}_{1}$, 微小侵潤癌では $\mathrm{aV}_{2}$, 扁平上皮侵潤癌 では $\mathrm{aV}_{3}$ が主体となって出現し, 病変の進行につ れて異型度および出現頻度の増加がうかがわれ た. 頝管壁所見として，粗造，白濁，凹凸不整や 壊死は圧倒的に侵潤癌(腺癌を含む)に多くみられ た。つぎに上皮内癌, 微小侵潤癌, 扁平上皮癌に ついて頝管内癌病変を実例を挙げて説明した。 以 上の結果, ヒステロスコピーによる頝管内癌病変 の検索は, 頝管癌の診断や細胞診と 組織診の不一 致例の検討のみならず, 円錐切除診の省略の可否 あるいは切除範囲の決定に, 有用であると考えら れる。 